10. DSTU EN 55014-1:2016 (EN 55014-1:2006; EN 55014-1:2006/ A1:2009; EN 55014-1:2006/A2:2011, IDT). Elektromahnitna sumisnist. Vymohy do pobutovykh elektropryladiv, elektrychnykh instrumentiv ta analohichnoi aparatury. Chastyna 1. Emisiia zavad. Kyiv: DP «UkrNDNTs», 2017. 94 p.

11. DSTU3680-98 (HOST 30586-98). Sumisnist tekhnichnykh zasobiv elektromahnitna. Metody zakhystu. Kyiv: Derzhstandart Ukrainy, 1999. $10 \mathrm{p}$

12. Walling E. M. High Power Microwaves: Strategic and Operational Implications for Warfare. Occasional Paper No. 11. Center for Strategy and Technology / Air War College / Air University / Maxwell Air Force Base. Alabama, 2000. 52 p. doi: http://doi.org/10.21236/ada425472

13. Geis J. P. Directed Energy Weapons on the Battlefield a New Vision for 2025. Occasional Paper No. 32 / Center for Strategy and Technology / Air War College / Air University / Maxwell Air Force Base. Alabama, 2003. 73 p. doi: http:// doi.org/10.21236/ada463429

14. Gizatullin Z. M. Tekhnologiya prognozirovaniya i povysheniya elektromagnitnoy sovmestimosti tsifrovykh elektronnykh sredstv pri vneshnikh vysokochastotnykh impul'snykh elektromagnitnykh vozdeystviyakh // Tekhnologii EMS. 2010. Issue 3 (34). P. $22-29$

15. Camp M., Nitsch D., Sabath F. Susceptibility of Electronic Equipment to HEMP Threats // System Design and Assessment Notes. Notes 37. 2004. 17 p.

16. Baker G., Castillo J. P., Vance E. F. Potential for a unified topological approach to electromagnetic effects protection // IEEE Transactions on Electromagnetic Compatibility. 1992. Vol. 34, Issue 3. P. 267-274. doi: http://doi.org/10.1109/ 15.155839

17. Tesche F. Topological concepts for internal EMP interaction // IEEE Transactions on Antennas and Propagation. 1978. Vol. 26 Issue 1. P. 60-64. doi: http://doi.org/10.1109/tap.1978.1141785

Fyk Oleksandr, PhD, Associate Professor, Department of Informatics and Information Technologies, National Academy of $\mathrm{Na}$ tional Guard of Ukraine, Kharkiv,Ukraine, e-mail: aifleks@ukr.net, ORCID: http://orcid.org/0000-0001-6735-6229

\section{Serikova E., Strelnikova E., Pisnia L.}

\title{
MATHEMATICAL MODELING OF CURTAIN GROUTING PARAMETERS FOR THE ROADWAYS FLOODING PREVENTION
}

Об’єктом дослідження є процес підтоплення дорожнього полотна в зоні впливу зрошувальних полів. Одним з найбільш проблемних місць є вплив таких техногенних факторів на рівень грунтових вод, як зрошувальні поля та автошлях, що переважають природні фактори. Надмірний вміст вологи знижує несучу здатність грунту, що призводить до прискореного руйнування і укорочення терміну служби дороги. У таких випадках для дороги з проблемами водовідведення потрібно більш частий ремонт і відновлення, ніж тій, на якій водовідведення функціонує нормально. Тому витрати на влаштування покриття необхідно порівнювати з витратами на підтримку водовідведення. Для збереження доріг та попередження їх підтоплення необхідний постійний контроль за станом рівнів грунтових вод (РГВ) та прогноз його змін.

В ході дослідження використовувалися математичні методи (аналітичне розв'язання диферениіальних рівнянь фільтрачї із залученням комп'ютерної програми Maple) для математичного моделювання параметрів протифільтраційної завіси. А також методи еколого-економічної оцінки та порівняльного аналізу для визначення вагомих факторів впливу на РГВ та впливу РГВ на довкілля.

Запропоновано інженерний захід для захисту дорожнього полотна від шкідливої дї грунтових вод, що передбачає встановлення протифільтраційної завіси вздовж автошляху. Проведене математичне моделювання параметрів протифільтращійних завіс, яке дозволить ефективно використовувати протифільтращійні завіси в боротьбі з підтопленням.

3 рівняння руху рідкого середовища Полубарінової-Кочіної, було отримано рівняння Дюпюї, яке використано для рішення стаціонарної задачі визначення витрати води крізь протифільтрачійну завісу. Далі було розв'язано стаціонарну задачу визначення витрати води крізь протифільтрачійну завісу. Встановлено, що використання протифільтраційної завіси є ефективним навіть при таких параметрах: $K_{\phi} \leq 0,7$ м/доб, при більшій довжині та меншому заглибленні самої завіси. Отримані розрахунки параметрів дозволять використовувати протифільтраційні завіси в різних галузях для захисту від підтоплення різноманітних господарських об'єктів.

Ключові слова: підтоплення автошляхів, зрошувальні поля, коефічієнт фільтрацї, математична модель параметрів протифільтращійних завіс.

\section{Introduction}

When constructing roads, special attention of project developers is paid to the traffic safety. The construction of roads and their maintenance in a satisfactory working condition takes a lot of effort, time and funding. In Ukraine, the problem of off-road is accepted to decide when traffic is no longer possible, especially with regard to inter-city traffic. Almost all regional roads become unsuitable for travel, especially those that lead to remote and mountain villages, where the road is the only thing that connects these settlements with the regional center. The road industry 
is financed on a residual basis. The problem of off-road in Ukraine has long been no news for anyone and everyone is used to the fact that the roads go every spring along with snow. In addition to natural factors affecting the sustainability of roads, there are factors of anthropogenic origin, in particular flooding, caused by the disturbance of the water balance of groundwater through irrigation of fields located along roads.

Therefore, it is important to solve the problem of groundwater drainage and surface run-off from roads. Road lanes that extend along irrigation fields are prone to local flooding and require special attention.

\section{The object of research and its technological audit}

The object of research is the roadway flooding process in the zone of irrigation fields influence.

The paper considers a section of the R51 motorway, which runs near the Gomolsha Forests National Natural Park (Zmiiv district, Kharkiv region, Ukraine), which unites such villages as Paseki and Zapadnia. The well, in which the groundwater level (GWL) was measured, is located $50-80 \mathrm{~m}$ from this section of the road.

Motorway R-51 is regional road of Ukraine, Merefa Pavlograd. It passes through the territory of Kharkiv and Zmiiv, Pervomaisk, Lozova districts of the Kharkiv region and Yurivka, Pavlograd districts of the Dnipropetrovsk region. The geographical location of the research object has been presented in Fig. 1. The well in which the GWL monitoring was conducted near the road has been shown in Fig. 2.

The well in which the GWL was measured, has the coordinates: $49^{\circ} 54^{\prime} 24^{\prime \prime} \mathrm{N}, 36^{\circ} 18^{\prime} 16^{\prime \prime} \mathrm{E}$. The measurements were taken by the Kharkiv complex geological expedition from 2006 to 2015 (Table 1) according to [1].

From the graph in Fig. 3 it can be seen that the depth of the groundwater occurrence at the research site does not always correlate with the precipitation amount. This can be explained by the effect of additional technogenic load from the impact of the road and irrigation fields on annual changes in groundwater levels.

Thus, technogenic factors of influence on this site are dominated by natural ones, which are caused by the influence of irrigation fields and roads on the change in the groundwater level [2]. Excess moisture content reduces the carrying capacity of the soil, which leads to accelerated destruction and shortening of the road life. In such cases, the road with drainage problems requires more frequent repair and restoration than the one on which the drainage system is functioning normally. Therefore, the cost of the device coverage should be compared with the cost of supporting wastewater.

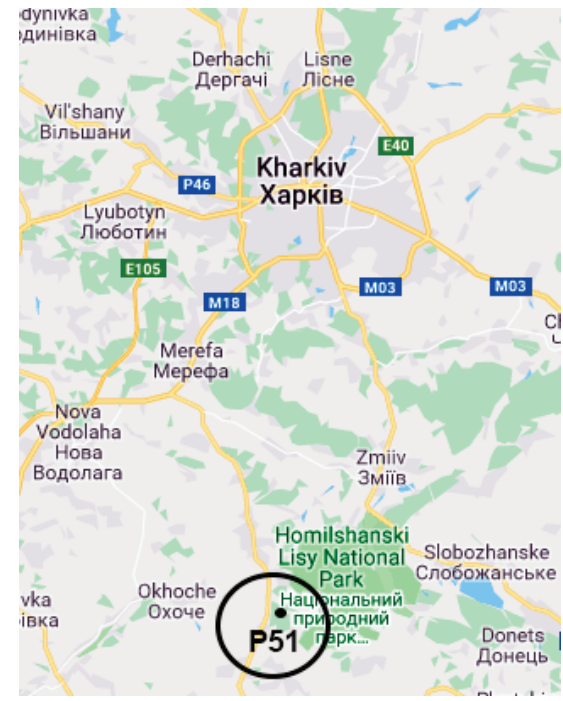

Fig. 1. Geographical location of the research object

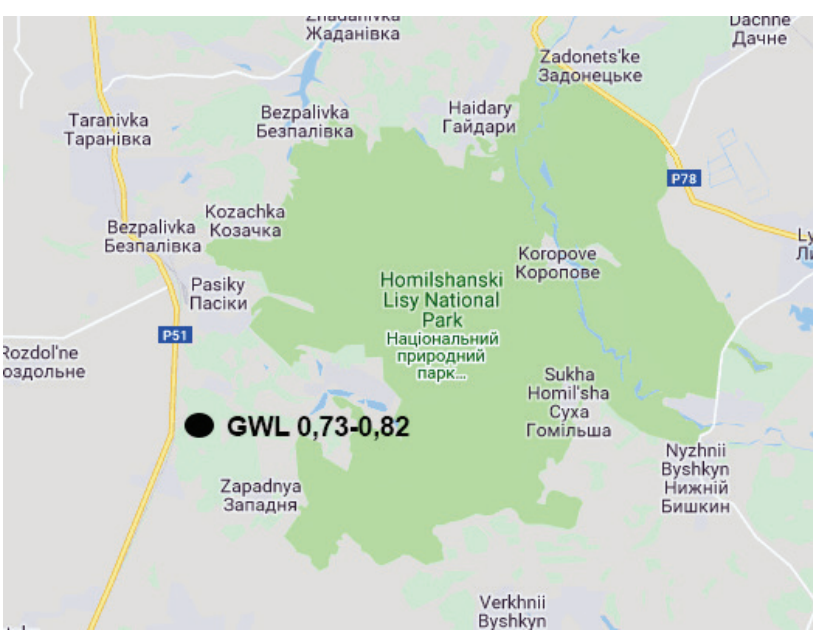

Fig. 2. The groundwater level monitoring well

Groundwater level at the control point

\begin{tabular}{|c|c|c|c|c|c|c|c|c|c|c|c|c|c|}
\hline \multirow{3}{*}{ Yеar } & \multicolumn{12}{|c|}{ Monthly mean values of groundwater levels (according to urgent observations) } & \multirow{3}{*}{$\begin{array}{l}\text { The average annual } \\
\text { values of groundwater } \\
\text { levels, } H_{a v 1} \mathrm{~m}\end{array}$} \\
\hline & \multicolumn{12}{|c|}{ Months } & \\
\hline & 1 & 2 & 3 & 4 & 5 & 6 & 7 & 8 & 9 & 10 & 11 & 12 & \\
\hline 2006 & 0.8 & 0.75 & 0.63 & 0.82 & 0.82 & 0.81 & 0.89 & 0.93 & 0.88 & 0.78 & 0.8 & 0.79 & 0.81 \\
\hline 2007 & 0.79 & 0.73 & 0.56 & 0.80 & 0.80 & 0.79 & 0.88 & 0.89 & 0.85 & 0.79 & 0.82 & 0.8 & 0.79 \\
\hline 2008 & 0.82 & 0.74 & 0.42 & 0.35 & 0.33 & 0.72 & 0.95 & 1.06 & 0.93 & 0.80 & 0.84 & 0.80 & 0.73 \\
\hline 2009 & 0.82 & 0.65 & 0.39 & 0.74 & 0.65 & 0.69 & 0.94 & 0.96 & 0.93 & 0.89 & 0.72 & 0.78 & 0.78 \\
\hline 2010 & 0.8 & 0.81 & 0.82 & 0.67 & 0.82 & 0.96 & 1.06 & 0.97 & 0.95 & 0.75 & 0.84 & 0.67 & 0.82 \\
\hline 2011 & 0.75 & 0.72 & 0.68 & 0.65 & 0.75 & 0.79 & 0.87 & 0.92 & 0.98 & 0.89 & 0.85 & 0.79 & 0.78 \\
\hline 2012 & 0.76 & 0.71 & 1.14 & 0.99 & 0.98 & 0.99 & 0.96 & 1.03 & 1.02 & 0.93 & 0.81 & 0.83 & 0.93 \\
\hline 2013 & 0.81 & 0.77 & 0.88 & 0.93 & 0.95 & 0.96 & 0.95 & 0.97 & 0.99 & 0.87 & 0.75 & 0.76 & 0.88 \\
\hline 2014 & 0.79 & 0.88 & 1.05 & 0.97 & 0.96 & 0.98 & 0.96 & 1.02 & 1.01 & 0.95 & 0.91 & 0.87 & 0.95 \\
\hline
\end{tabular}




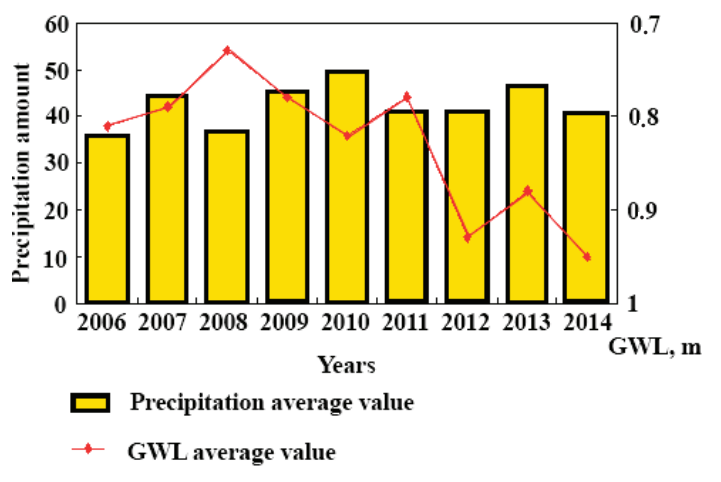

Fig. 3. Average values of the groundwater level depth and the precipitation amount of over the study period from 2006 to 2014

In Ukraine, repair and maintenance of roads is carried out in accordance with the document «P-G.1-218-113: 2009. Technical rules for the repair and maintenance of public roads in Ukraine» [3]. But there is no special document on strengthening roadsides of roads, which should contain rules and guidelines for strengthening roadsides and diversion of water in Ukraine. Only the document from 1980 is used: «BSN 39-79. Technical guidelines for strengthening roadsides of highways» [4]. For example, in Russia there is «ODN 218.3.039-2003. Strengthening the roadsides of highways» [5].

\section{The aim and objectives of research}

The aim of research is prevention of flooding of roads by installing curtain grouting. To achieve this aim it is necessary to perform the following tasks:

1. To substantiate the effect of technogenic factors on the change in the groundwater level.

2. To offer an engineering measure to protect the roadway from the harmful effects of groundwater.

\section{Research of existing solutions of the problem}

In [6] an inventory of flooding resulting from the construction of roads has been carried out. The problem of flooding is considered only by the human impact of roads on the flooding development. But the influence of flooding on road stability, and the effect of irrigation fields near highways on changes in groundwater levels has not been considered. That is, the issue has not been considered comprehensively and number of important technogenic factors have not been taken into account.

The author of [7] gives options for the use of curtain grouting in cities, both to protect against flooding of individual sites, buildings and structures, and for the construction of supporting and enclosing structures and foundations. The author focuses only on one type of curtain grouting - reinforced concrete, to protect metro stations from the groundwater action. However, curtain grouting with excellent parameters has not been considered.

The results of the comprehensive study of the microstructure and filtration intensity of curtain grouting have been highlighted in [8]. However, there is an unresolved question of the length and depth of the curtain grouting immersion.

The authors of [9] investigate the curtain grouting effectiveness to protect the dam foundation. Studies have been conducted for a limited number of options for the choice of materials for curtain grouting, which limits the use of curtain grouting.

The concept of «composite wall» as curtain grouting using clay and concrete as the main components of the curtain, has been presented in [10]. But the authors provide a detailed justification of the parameters of only two types of curtain grouting: clay and concrete, and suggest using curtains in cramped conditions.

The existing filtration calculations methods with low power of groundwater flows and at the beginning of nonwatered soils [11, 12] do not cover all important cases of flooding and drainage. For example, previously the exact solution was not known for radial spreading over the water resistance in non-irrigated soils, as well as other cases.

The latest publications on surface watering and lowpower groundwater flows [13] contain solutions within the framework of the linearized hydraulic filtration theory. And they are private in nature with idealized statements about infinitely distant boundaries of influence, that is, with fairly approximate solutions.

The publications review $[14,15]$ shows that the existing methodology for predicting flooding and drainage from different authors actually does not take into account the influence of structures and construction technologies.

At the same time, new and original designs of fortifications are appeared, including prefabricated trellised, flexible asphalt and reinforced concrete, with the use of geotextiles, geocontainers and number of others. The generalization beginning of fortifications various types have been laid in [16, 17]. However, a scientifically based solution to this issue in the development and improvement of new designs is associated with the need to form the theoretical and conceptual foundations for the fortifications design. The beginning of the development of such bases belongs to the author of [13].

Thus, the results of literary analysis allow to conclude that the curtain grouting implementation can have a wider range of uses, due to the simulation of their parameters.

\section{Methods of research}

Mathematical methods were used (analytical solution of differential filtration equations involving the Maple computer program) for mathematical modeling of the curtain grouting parameters. As well as methods of environmental and economic assessment and comparative analysis to determine significant factors influencing the GWL and the impact of GWL on the environment.

The curtain grouting arrangement (Fig. 4) along the road to protect the roadway from the harmful effects of groundwater has been proposed.

It has been solved stationary problem of determining the water flow through curtain grouting.

The resulting formulas for the sequential calculation of the heads on the curtain walls:

$$
\begin{aligned}
& H_{2}=\sqrt{\frac{H_{4}^{2}+\frac{H_{4}^{2} \cdot L_{3}}{L_{1}} \cdot\left(1+\frac{K \cdot L_{2}}{K_{z} \cdot L_{3}}\right)}{1+\frac{L_{3}}{L_{1}}\left(1+\frac{K \cdot L_{2}}{K_{z} \cdot L_{3}}\right)} ;} \\
& H_{3}=\sqrt{H_{4}^{2}+\left(H_{1}^{2}-H_{2}^{2} \cdot \frac{L_{3}}{L_{1}}\right)},
\end{aligned}
$$


where $H_{2}$ and $H_{3}$ - heads on the curtain walls, m; $H_{1}$ and $H_{4}$ - heads without curtain, m; $L_{2}$ - curtain length, m; $L_{1}, L_{3}$ - distance to the curtain, $\mathrm{m} ; K_{z}$ - curtain filtration coefficient; $K$ - soil filtration coefficient. $H_{2}$ is first determined and then $\mathrm{H}_{3}$.

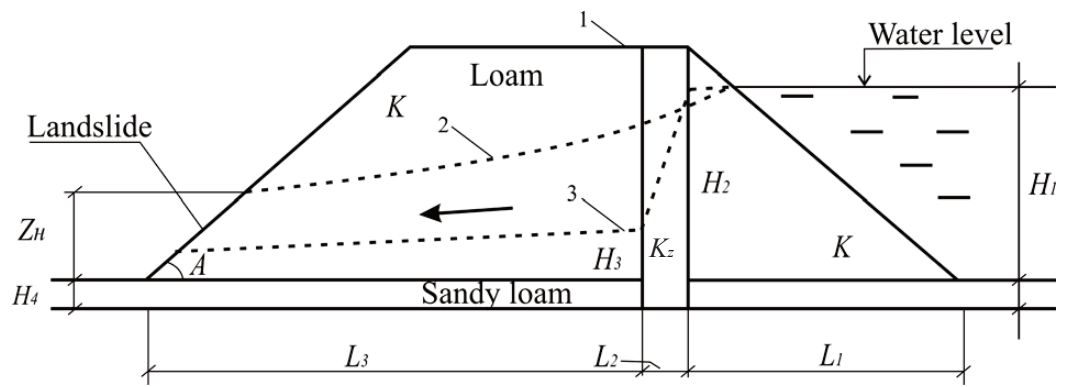

Fig. 4. Diagram of the cross section of the soil mound of reclaimed territories: 1 - curtain grouting; 2 - depression curve without a curtain; 3 - the same with a curtain
At $K_{f}>0.3 \mathrm{~m} /$ day, the curtain grouting efficiency is significantly reduced, while its depth becomes an insignificant parameter.

2 . In the second version of the calculations, the length of the curtain is extended to $10 \mathrm{~m}$ (Fig. 6) at $L_{1}=1$; $L_{2}=0.1 ; L_{3}=1 ; H_{1}=10 ; H_{4}=1$.

Thus, Fig. 6 shows that the longer the curtain is, the less it needs to be deepened. The dependence of the curtain depth on its length is studied in direct proportion.

Fig. 7 shows rate graphs with and without curtain.

From Fig. 7 it is possible to see that the curtain is effective at $K_{f}<0.1 \mathrm{~m} /$ day.

Fig. 8 shows the case when the curtain length is increased to $10 \mathrm{~m}$.

From Fig. 8 it is possible to see that even at $K_{f} \leq 0.7 \mathrm{~m} /$ day and the extended curtain length, its use is effective.
Next is the flow rate by Dupuit:

a) through the curtain:

$$
Q_{z}=\frac{K_{z} \cdot\left(H_{2}^{2}-H_{3}^{2}\right)}{2 L_{2}}
$$

where $Q$ - filtration flow rate, $\mathrm{m}^{3} / \mathrm{s}$.

b) through the mound without a curtain:

$$
Q=\frac{K \cdot\left(H_{1}^{2}-H_{4}^{2}\right)}{2\left(L_{1}+L_{2}+L_{3}\right)} \text {. }
$$

Thus, the stationary problem of determining the water flow through the curtain grouting has been solved.

To simulate the effectiveness of establishing curtain grouting, formulas have been obtained for calculating the curtain grouting depth and its effect on filtration rate by Dupuit and on the height of the seepage section.

\section{Research results}

The depth of the curtain grouting has been investigated for various parameters (Fig. 5):

1. For different filtration coefficients $K_{f}=0.1 ; 0.2 ; 0.3$ $L_{1}=L_{2}=L_{3}=1 ; H_{1}=1, H_{4}=10$.

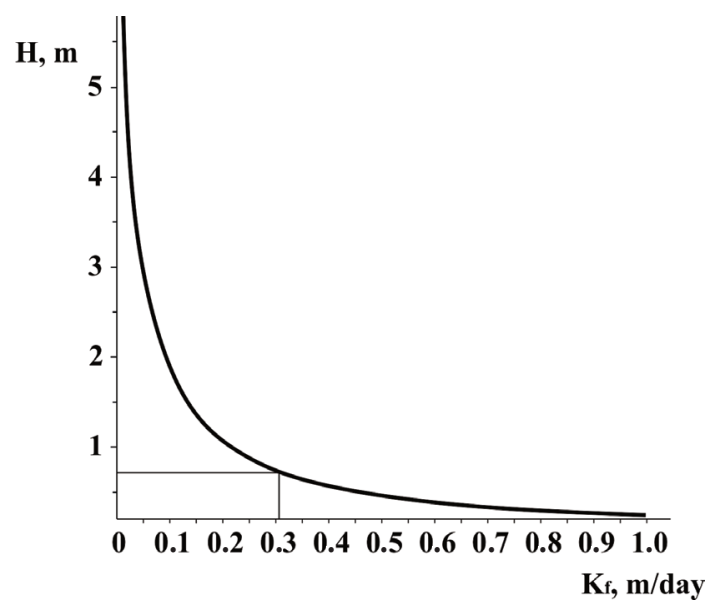

Fig. 5. Depth of curtain grouting at different filtration coefficients: $H$ - curtain depth, $\mathrm{m} ; K_{f}-$ filtration coefficient, $\mathrm{m} /$ day

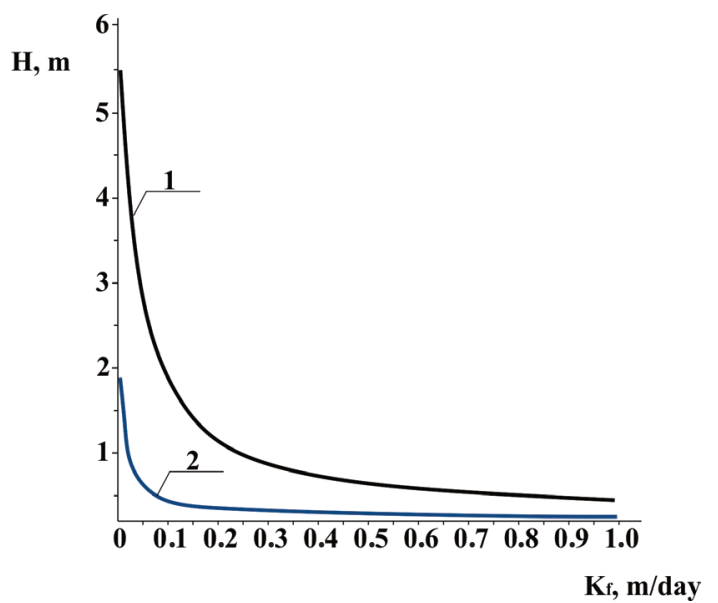

Fig. 6. Depth of curtain grouting at different filtration coefficients and length: $H$ - curtain depth, $\mathrm{m} ; K_{f}-$ filtration coefficient, $\mathrm{m} /$ day;

1 - the original version of the calculation (Fig. 5); 2 - extended curtain length

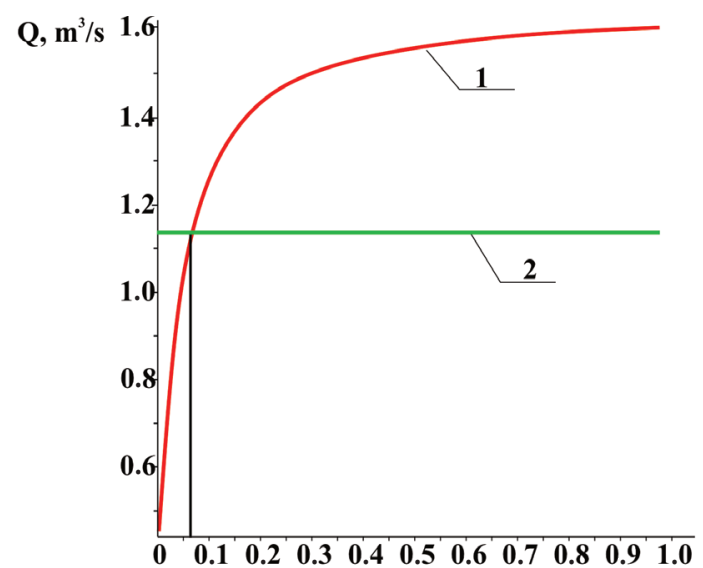

Kf, m/day

Fig. 7. Rate graphs with and without curtain: $\square$ - water rate, $\mathrm{m}^{3} / \mathrm{s} ; K_{f}$ - filtration coefficient, $\mathrm{m} /$ day; 1 - water rate with a curtain; 2 - water rate without a curtain 


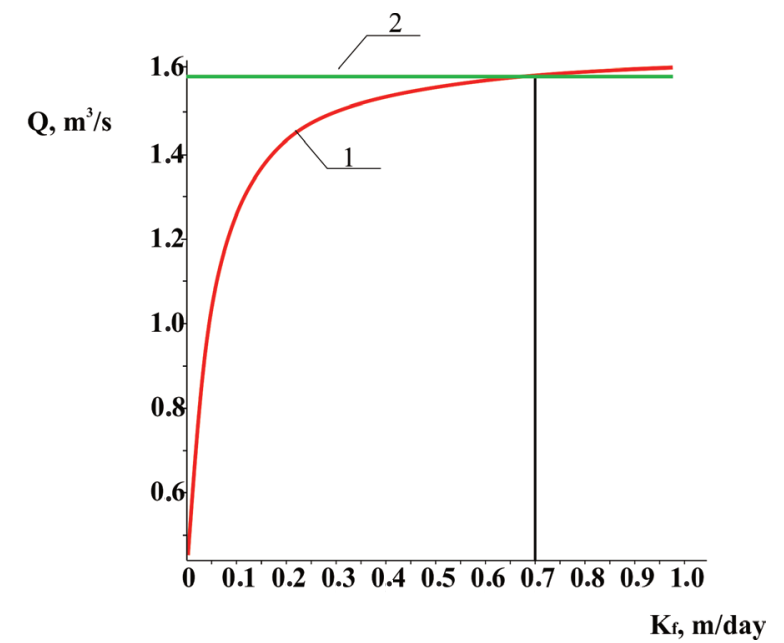

Fig. 8. Rate graphs with and without curtain with a curtain length $L=10 \mathrm{~m}$ : $\square$ - water rate, $\mathrm{m}^{3} / \mathrm{s}$; $K_{f}$ - filtration coefficient, $\mathrm{m} /$ day; 1 - water rate with a curtain; 2 - water rate without a curtain

From the Polubarinova-Kochina equation of the liquid medium motion [11], the Dupuit equation has been obtained, which was used to solve the stationary problem of determining the water flow rate through the curtain grouting. Further, according to formulas (1)-(4) [18], the stationary problem of determining the water flow through the curtain grouting has been solved. It has been established that the curtain grouting implementation is effective even at $K_{f} \leq 0.7 \mathrm{~m} /$ day, and with a greater length and a smaller deepening of the curtain itself.

\section{SWOT analysis of research results}

Strengths. The effect of the additional technogenic load from the impact of the road and irrigation fields on the annual changes in groundwater levels has been substantiated. An arrangement of curtain grouting along the road to protect the roadway from the harmful effects of groundwater has been proposed. It has been solved the stationary problem of determining the flow rate through the curtain grouting and the parameters of curtain grouting to prevent roads flooding. This will allow to use the curtain grouting in various industries to protect against flooding of various objects.

Weaknesses. Calculations on the model show that the use of curtain grouting affects, but not very intensively on the filtration flow decrease.

Opportunities. Local use of curtain grouting is also possible to protect construction sites from the groundwater harmful effects in built-up areas.

A more effective means of preserving roads may be the arrangement of drainage in the lower part of the road embankment. This event will ensure complete interception of the filtration flow with the elimination of seepage areas and landslides.

Threats. The construction of roads and their maintenance in the satisfactory working condition takes a lot of effort, time and funding. In Ukraine, the problem of off-road is accepted to decide when traffic is no longer possible, especially with regard to inter-city traffic. Almost all regional roads become unsuitable for travel, especially those that lead to remote and mountain villages, where the road is the only thing that connects these settlements with the regional center. The road industry is financed according to the residual principle and there is usually not enough money for expensive research and forecasting changes in the groundwater level. To preserve the roads and prevent their flooding, constant monitoring of the state of the groundwater table, water bodies, irrigation fields and economic objects near roads and a forecast of their changes are necessary [19, 20].

\section{Conclusions}

1. It has been revealed that the groundwater depth of the occurrence at the research site does not always correlate with the amount of precipitation. In particular, in the period from 2011 to 2014, GWL is reduced by $0.2 \mathrm{~m}$, and then increases by $0.1 \mathrm{~m}$, while the amount of precipitation remained unchanged. This can be explained by the effect of additional technogenic load from the impact of the road and irrigation fields on annual changes in groundwater levels. That is, technogenic factors of influence on this site are dominated by natural ones.

2. An engineering measure has been proposed to protect the pavement from the harmful effects of groundwater, providing for the installation of curtain grouting along the road. The mathematical modeling of the curtain grouting parameters has been carried out, which will make it possible to effectively use the curtain grouting in the fight against flooding.

From the Polubarinova-Kochina equation of the liquid medium motion [11], the Dupuit equation has been obtained, which was used to solve the stationary problem of determining the flow water rate through the curtain grouting. Further, according to [18], the stationary problem of determining the water flow through the curtain grouting has been solved. It is established that the use of curtain grouting is effective even at such parameters: $K_{f} \leq 0.7 \mathrm{~m} /$ day, with a greater length and a smaller deepening of the curtain itself.

\section{References}

1. Olshanska I., Rudyi M., Pedan V. Monitorynh pidzemnykh vod na terytoriyi Sumskoi ta Kharkivskoi oblastei. Zvedenyi informatsiynyi zvit Kharkivskoi kompleksnoi heolohichnoi ekspedytsii za 2006-2015 rr. 2016. 256 p.

2. Serikova E. N., Yakovlev V. V. Additional infiltration into the groundwater at the metropolitan area (for example, Kharkov) // Municipal economy of cities. Series: Engineering Sciences and Architecture. 2011. Issue 97. P. 344-348.

3. Pravyla No. 190 vid 1997-09-26. Tekhnichni pravyla remontu ta utrymannia avtomobilnykh dorih zahalnoho korystuvannia Ukrainy P-H.1-218-113-97.

4. RSFSR. 20.03,79 g. Tekhnicheskie ukazaniya. po ukrepleniyu obochin. avtomobil'nyh dorog. VSN 39-79.

5. ODN 218.3.039-2003 (utv. rasporyazheniem Mintransa RF ot 23.05.2003 N OS-461-r).

6. Razvitie podtopleniy vdol' nasypnyh dorog $\mathrm{v}$ usloviyah lesotundry Zapadnoy Sibiri / Milyaeva E. V. et. al. // Vestnik Tomskogo gosudarstvennogo universiteta. 2012. Issue 365. P. 206-211.

7. Sologaev V. I. Zashchita ot podtopleniya v gorodskom stroitel'stve. Ustroystvo i rabota. Omsk: SibADI, 1999. 56 p.

8. Aver'yanov V. N. Evaluation of the Impermeability of a Curtain Formed from Alluvial Clayey Loams Based on Study of the Microstructure of the Soil and Filtration Investigations // Power Technology and Engineering. 2014. Vol. 47, Issue 5. P. 326-331. doi: https://doi.org/10.1007/s10749-014-0447-4

9. Mordvintsev K., Alwahab Y. A. Evaluation of the Effectiveness of the Creation of Antifiltration Curtains in Hydroelectric Power Plant in Syria // Advances in Intelligent Systems and Computing. 2017. P. 634-639. doi: https://doi.org/10.1007/9783-319-70987-1_67 
10. Bruce D. A., Dreese T. L., Heenan D. M. Concrete walls and grout curtains in the twenty-first century: the concept of composite cut-offs for seepage control // USSD 2008 Conference. Portland, 2008. 35 p.

11. Polubarinova-Kochina P. Ya. Teoriya dvizheniya gruntovyh vod. Moscow: Nauka, 1977. 664 p

12. Barenblatt G. I., Entov V. M., Ryzhik V. M. Dvizhenie zhidkostey i gazov v prirodnyh plastah. Moscow: Nedra, 1984. 211 p.

13. Perevoznikov B. F. Zashchita avtomobil'nyh dorog ot opasnyh gidrometeorologicheskih processov i yavleniy. Moscow: Informavtodor, 1993

14. Prognozy podtopleniya i raschet drenazhnyh sistem na zastraivaemyh i zastroennyh territoriyah: sprav. pos. / Muftahov A. Zh. et. al. Moscow: Stroyizdat, 1991. 272 p.

15. Rudakov V. K. Metody prognoznyh raschetov vliyaniya orosheniya na rezhim gruntovyh vod // Voprosy gidrogeologichnskih prognozov v svyazi s irrigaciey zemel' i vodosnabzheniem. Trudy Dnepropetrovskogo gosudarstvennogo universiteta. 1970. Issue 3. P. 123-127.

16. L'vovich Yu. M. Sovremennye konstrukcii i metody ukrepleniya na ob'ektah dorozhno-mostovogo stroitel'stva. Moscow: CBNTI Minavtodora RSFSR, 1980. 69 p.

17. L'vovich Yu. M., Motylev Yu. L. Ukreplenie otkosov zemlyanogo polotna avtomobil'nyh dorog. Moscow: Transport, 1979. $199 \mathrm{p}$.
18. Zolotarev N. V. Modelirovanie podtopleniya i drenirovaniya melioriruemyh landshaftov metodom elektronnyh tablic s cel'yu prognozirovaniya ih sostoyaniya: Abstract's PhD thesis. Omsk, 2013. 22 p.

19. Serikova E., Strelnikova E., Yakovlev V. The Programme of Measures to Prevent Flooding on the Built-up Areas on Example of Kharkiv City // International Journal of Development Research. 2015. Vol. 5, Issue 12. P. 6236-6240.

20. Serikova E. N., Yakovlev V. V. Rol' upravlencheskih metodov $\mathrm{v}$ predotvrashchenii podtopleniya gorodov // Naukovyi visnyk budivnytstva. 2012. Issue 68. P. 382-387.

Serikova Elena, Environmental Engineer, A. N. Pidgorny Institute for Mechanical Engineering Problems of the National Academy of Sciences of Ukraine, Kharkiv, Ukraine, ORCID: http://orcid.org/ 0000-0003-0354-9720

Strelnikova Elena, Doctor of Technical Sciences, Leading Researcher, A. N. Pidgorny Institute for Mechanical Engineering Problems of the National Academy of Sciences of Ukraine, Kharkiv, Ukraine, e-mail: elena15@gmx.com,ORCID: http://orcid.org/0000-0003-0707-7214

Pisnia Leonid, PhD, Research Institute «Ukrainian Research Institute of Environmental Problems», Kharkiv, Ukraine, e-mail: leonid pisnya@ukr.net,ORCID:http://orcid.org/0000-0002-3603-9412

\section{Akimova 0., Kravchenko 0 .}

\section{DEVELOPMENT OF THE METHODOLOGY OF THE CHOICE OF THE ROUTE OF WORK OF PLATFORM SUPPLY VESSELS IN THE SHELF OF THE SEAS}

Об'єктом дослідження є організачія роботи спеціалізованих суден постачання видобувних платформ (СПП) в шельфах морів. Одним з найбільш проблемних місиь є необхідність підвищення ефективності роботи спеціалізованих судів обслуговування для доставки персоналу, будівельних матеріалів і постачання на нафтові платформи в шельфах морів під час експлуатації платформ для видобутку нафти.

В ході дослідження для вдосконалення роботи СПП при розробці методології використовувалися метод варіантів і марирутизації роботи наземних транспортних засобів. Це дозволило удосконалити роботу СПП при обслуговуванні видобувних платформ, завдяки зниженню собівартості виконання рейсів.

Отримано найкращий маршрут та спосіб організації роботи СПП при обслуговуванні видобувних платформ, на прикладі шельфу Чорного моря (Україна). А саме, складені можливі маршрути роботи СПП при маятниковому і збірно-розвізному способі роботи, а також за обраним критерієм визначено кращий спосіб роботи СПП для найкращого маршруту. Розраховано економічний ефект від роботи СПП за обраним маршрутом і способом, який склав близько 44 тис. дол. за рейс. Це пов'язано з тим, що розроблена методологія щодо вибору найкращого варіанту роботи СПП має ряд особливостей, зокрема вона складається з послідовних етапів:

- вибираютвся схеми маршрутів по організації роботи СПП;

- складаються варіанти маршрутів роботи СПП за кожною схемою;

- призначається критерій вибору схеми;

- розраховуються показники роботи судів;

- вибирається оптимальний марирут і схема за прийнятим критерієм оптимізаиії.

Розроблена методологія забезпечує визначення оптимального маршруту і варіанти схеми роботи СПП, який забезпечує найменше значення собівартості перевезень 1 тонно-км вантажів. У порівнянні з аналогічними відомими методами, які застосовуються в автомобільному транспорті, в морському нафтовидобувному бізнесі подібні методи не застосовувалися.

Ключові слова: спеціалізовані судна постачання видобувних платформ, морські бурильні платформи, варіанти марирутів роботи.

\section{Introduction}

According to the State Informational Geological Fund («Geoinform»), as of January 1, 2017, Ukraine is developing 269 objects of combustible gaseous minerals, with a volume of 798.442 million $\mathrm{m}^{3}$ and 135 combustible liquid minerals, with a volume of 121.124 million tons. 3 Gas facilities on the shelf of the Azov Sea, with a volume of 10.534 million $\mathrm{m}^{3}$, and two oil volumes of 5.425 million tons and on the shelf of the Black Sea three gas facilities of 3.7506 million $\mathrm{m}^{3}$, and 